\title{
Heat Pipes for Steam Condensation
}

\author{
${ }^{1}$ T. Mallikharjuna Rao, ${ }^{2}$ Dr. S. S. Rao \\ ${ }^{1}$ Joint Director. Central Power Research Institute, TRC, Koradi, Nagpur-441 111,INDIA \\ ${ }^{2}$ Professor, Mechanical Engineering Dept National Institute of Technology Warangal - 506 004, INDIA
}

\begin{abstract}
This paper explores the feasibility of using the heat pipe for steam condensation. In this paper an attempt is made to replace thousands of condenser tubes by hundreds of "Heat Pipes". The design details of heat pipe, that is, material of heat pipe, heat pipe length, diameter of heat pipe for condensation purpose is described. The feasibility study was carried out for smooth operation of the heat pipe that is without ceasing during operation. Experimental setup and results of steam condensation studies are presented.
\end{abstract}

Keywords: Wickless heat pipe, thermal syphon, steam condenser, heat transfer coefficient,

\section{Introduction}

Historical Development of heat pipes dates back 1942 when the first Patent for a heat pipe employing a capillary wick for pumping liquid against gravity was applied by Gaugler (1942) . In the words of Grover $(1963,1964)$ who along his co-workers reinvented the 'heat pipe' in 1963 , a heat pipe is a "... synergistic engineering structure which is equivalent to a material having thermal conductivity greatly exceeding that of any known metal...". In other words , a heat pipe is a passive two -phase heat transfer device capable of transferring large quantities of heat with minimum temperature drop.In 1964 , RCA was the first commercial organisation to perform heat pipe research. Due to the its commendable ability to transport heat energy the use of heat pipe becoming popular, starting from space shuttles to electronic industry.(14)

\section{Literature Review}

The special features of heat pipes have made them attractive for use as heat pipe heat exchangers (HPHE). Dunn and Reay (1) in his book reported various applications of heat pipes viz. Heat pipes in energy storage system, Heat pipes in chemical reactors, Heat pipes for space craft applications, Energy conservation and renewable energy applications, Preservation of permafrost, Snow melting and deicing applications, Heat pipes for food industry applications, Heat pipes in medical and surgical technologies, Cooling of gas turbines

Amir Faghri (4) described in his book the application of heat pipes for heat exchanger applications. He described the Heat pipe heat exchanger (HPHE) is similar to a liquid-coupled indirect transfer type heat exchanger except that HPHE employs heat pipes or thermosyphons, which uses the evaporation and condensation of a working fluid within the heat pipe as the major heat transfer mechanism from the high temperature to the low temperature fluid, and do not require an external pump to circulate coupling fluid. He also stated that most of HPHE's use thermosyphons because they have higher maximum heat transport capacity and are easier to manufacture than wicked heat pipes. Faghri classified HPHE applications into three main categories

(i) Heat recovery in air Conditioning devices

(ii) Heat recovery from the process exhaust steam to preheat air for space heating

(iii) Heat recovery from the process exhaust steam for re-use in the process.

Various research workers reported the application of heat pipes for preheat combustion air in fossil fired power plants and in process furnaces, the Heat exchanger using Heat pipes for heat exchange between metallic sodium and water, the Heat pipe type Heat Exchanger for use in combination with a fast breeder reactor, HPHE is the recovery of heat from exhaust gases in industrial plants, heat pipe coolers for electronic cabinets.

L.L Vasiliev in 2005 (25) reviewed usage of Heat pipes in modern heat exchangers. He reported that, heat pipes are very flexible systems with regard to effective thermal control. They can easily be implemented as heat exchangers inside sorption and vapour-compression heat pumps, refrigerators and other types of heat transfer devices. Their heat transfer coefficient in the evaporator and condenser zones is $10^{3}-10^{5} \mathrm{~W} / \mathrm{m}^{2} \mathrm{~K}$, heat pipe thermal resistance is $0.01-0.03 \mathrm{~K} / \mathrm{W}$, therefore leading to smaller area and mass of heat exchangers. Miniature and micro heat pipes are welcomed for electronic components cooling and space two-phase thermal control systems. Thermal siphons ,Loop heat pipes, pulsating heat pipes and sorption heat pipes are the novelty for modern heat exchangers. Heat pipe air preheaters are used in thermal power plants to preheat the secondaryprimary air required for combustion of fuel in the boiler using the energy available in exhaust gases. Heat pipe 
solar collectors are promising for domestic use. But all these application are for energy recovery, air to air, air to gas exchanges and liquid to liquid only. Till now no application is made to condensate the steam using heat pipes.

\section{The Design Of Heat Pipe For Steam Condensation}

An attempt made to use heat pipes for steam condensation. For steam condensation, a heat pipe was designed .The line diagram of the heat pipe is shown in Fig. 1 and design details are given below. (Patent for this design is applied)

Length of the Heat pipe $=\mathrm{L}=4.3 \mathrm{~m}$

Length of evaporator section $=\mathrm{L}_{\mathrm{e}}=2 \mathrm{~m}$

Length of the condenser section $=\mathrm{L}_{\mathrm{c}}=2 \mathrm{~m}$

Length of the adiabatic section $=1_{\mathrm{a}}=0.3 \mathrm{~m}$

Tube is ' $\mathrm{K}$ ' type Nominal Standard Size is 2 inch

Outside diameter of the heat pipe $=\mathrm{d}_{\mathrm{o}}=2.125$ inch $=0.053975 \mathrm{~m}$

Inside diameter of the heat pipe $=\mathrm{d}_{\mathrm{i}}=1.959 \mathrm{inch}=0.0497586 \mathrm{~m}$

Thickness of the heat pipe wall $=\mathrm{t}=0.083$ inch $=2.1082 \times 10^{-3} \mathrm{~m}$

The heat pipe is a wickless, gravity assisted that is strictly it is a two phase

closed thermosyphon

Vacuum inside heat pipe $=0.07$ bar

Hence Saturation temperature for water inside heat pipe $=39.02^{\circ} \mathrm{C}$

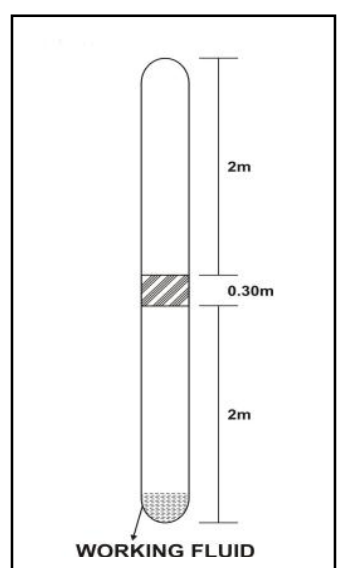

Fig 1

The steam incidents on the heat pipe evaporator surface at $100^{\circ} \mathrm{C}$. The evaporator will be having the water at a pressure of $0.07 \mathrm{bar}$. At this pressure the boiling temperature of the water is $39.02{ }^{\circ} \mathrm{C}$. Hence the working fluid inside heat pipe (water) starts boiling. The vapors from the evaporator regions enters the condenser portion of heat pipe. This portion is maintained at a surface temperature of $27^{\circ} \mathrm{C}$ with help of inlet cooling water. So the vapors which reached the top portion of the heat pipe will condense on side surface of the heat pipe by releasing heat gained at evaporator section to the cooling water. The condensate will flow down due to gravity. The cycle repeats as the process go on.

\section{4.0 Design And Fabrication Of Experimental Set Up}

The line diagram for the heat pipe based condenser experimental set up is shown in Fig 2. Steam inlet entry to the condenser will be from the both sides as shown in the figure. The cooling water will be entered inside the condenser just above separator plate and exited from the top portion. The condensate will be flooded to the bottom of the condenser. The heat pipes will be arranged in $80 \times 80$, vertical, staggered arrangements. The plan of the arrangement of heat pipes is shown in Fig .4

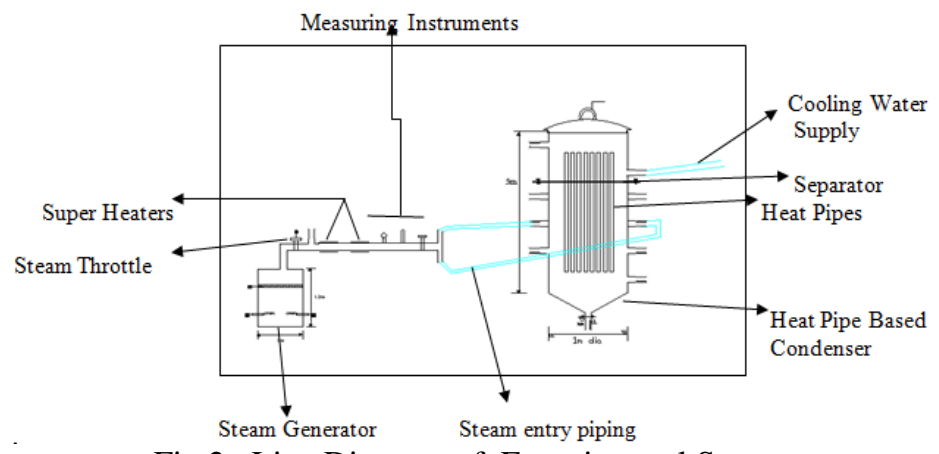

Fig 2. Line Diagram of Experimental Set up

The actual fabrication of experimental set up shown in Fig3. The experimental set up consists a steam generator , heat pipe based condenser, connecting pipes and instrumentation. 


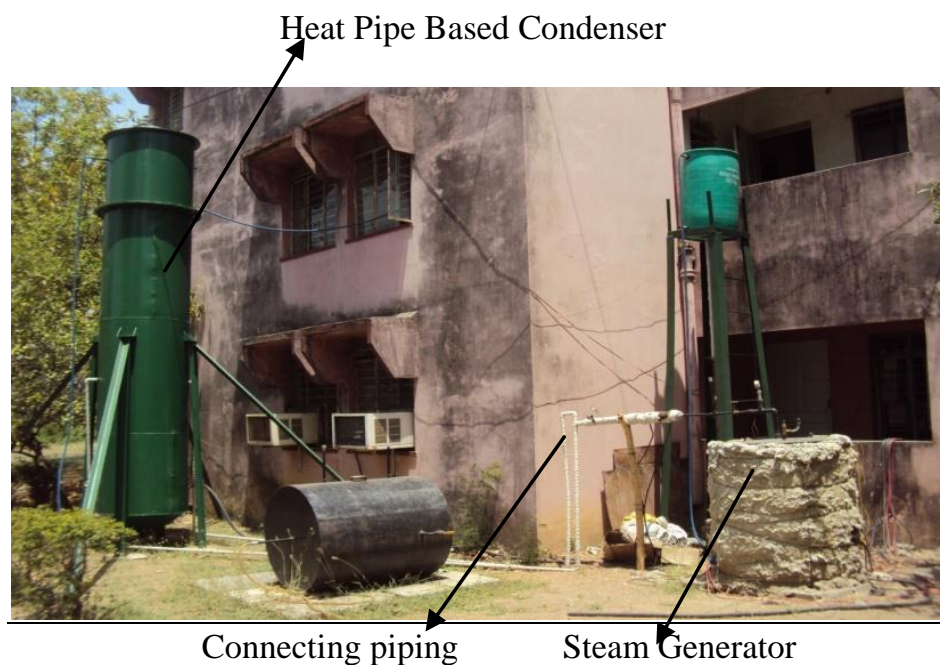

Fig 3. Total Experimental Set up.

\section{Experimental Results}

The steam from the boiler at a temperature $\left(>110^{\circ} \mathrm{C}\right)$ is fed into the heat pipe based condenser. This steam condensates in the condenser with help of heat pipes and water is collected from the bottom of the condenser (Shown in Fig 4). The temperature of the condensate is around $40^{\circ} \mathrm{C}$.

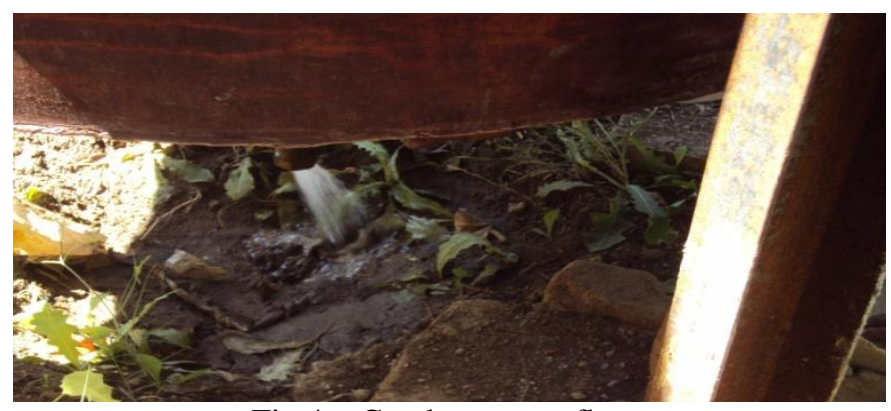

Fig 4 : Condensate outflow

\section{Analysis Of Experiments}

Steam generator is loaded with electrical heaters. The experiment conducted for one hours after initial heating of feed water.

Power consumed during the one hour $=11.73 \mathrm{KWH}$

Steam pressure maintained $=1.4 \mathrm{bar}$

Temperature of steam $=100^{\circ} \mathrm{C}$

Boiler efficiency considered is $80 \%$

Hence steam produced will be $15 \mathrm{~kg} / \mathrm{hr}$

The steam produced is superheated and throttled before entering into the condenser.

The condenser is built with 16 heat pipes which are described earlier.

The condensate collected is 13 lit in one hour.

Like this three experiments were conducted and results are shown as below.

\begin{tabular}{|c|c|c|c|}
\hline Experiment No & Steam Inlet Temperature in ${ }^{\mathbf{}} \mathbf{C}$ & Steam inlet Pressure in Bars & Condensate collected in Liters \\
\hline 1 & 106 & 0.22 & 11 \\
\hline 2 & 126.6 & 0.26 & 12 \\
\hline 3 & 164.5 & 0.41 & 13 \\
\hline
\end{tabular}

The graphical representations are as below. 

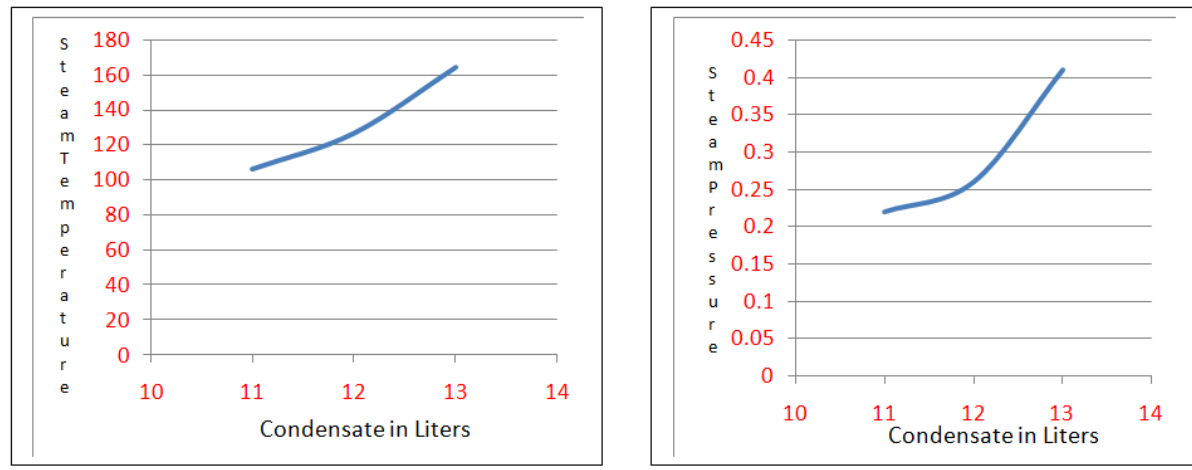

\section{Coclusion And Usefulness To Power Plants}

This experiment proved that Heat pipes can be used for steam condensation purpose. Due to the usage of heat pipes, there will be considerable reduction in the heat transfer surface area. Hence number of tubes carrying cooling liquid will be reduced which results easy of operation and low maintenance problems in Power Plant Condensers.

\section{Acknowledgements}

The authors would like to thank M/s. Central Power Research Institute for sponsoring the experimental expenditure and gave permission to publish this article.

\section{References}

[1] Heat Pipes ,Second Edition, P.Dunn and D.A. Reay, Pergamon Press.

[2] Gaugler, R. S., "Heat Transfer Device," U. S. Patent

[3] Grover, G. M., Cotter, T. P., and Erikson, G. E., "Structures of Very High ThermalConductivity," J. Applied Physics, 35, 1990 (1964)

[4] Amir Faghri "Heat Pipe Science and Technology" Taylor and Francis, Washngton Dc,USA, 1995

[5] F. Yang, X. G. Yuan, G . P. Lin, Waste heat recovery using heat pipe heat exchanger for heating automobile using exhaust gas, Applied Thermal Engineering 23 (3) ,2003, 367-372.

[6] S. H. Noie, M. Lotfi, Energy conservation by waste heat recovery in industry using thermosyphon heat exchangers, International solar Energy System, Adelaide, Australia, 2001, pp. 141.

[7] V. Dube, S. H. Noie, B. Awasthi, A. Akbarzadeh, P. W. Johnson, Waste heat recovery using loop thermosyphons heat exchanger (LTHE) in Buttercup bakery, Proceeding of sixth International Heat Pipe Symposium, Thailand . 2000, pp. 174-183.

[8] J . Y. Sun, R. J. Shyu, Waste heat recovery using heat pipe heat exchanger for industrial practices, Proceeding of fifth International Heat Pipe Symposium, Melbourne, Australia, 1996, pp . 287-295.

[9] S. H. Noie, Investigation of thermal performance of an air - to - air thermosyphon heat exchanger using - NTU method, Applied Thermal Engineering 26, 2006, $559-567$.

[10] Robert S. Reid and Michael A. Merrigan ,Los Alamos National Laboratory, USA "Heat Pipe Activity in the Americas - 1990 to 1995

[11] MA Tongze and Hou Zengqi, "Heat Pipe Research and Development in China" published in Heat Recovery systems \& CHP , 1989

[12] Hong Zhang, Jun Zhuang "Research, development and industrial application of heat pipe technology in China published in 2003 in Applied Thermal Engineering 23 (2003) 1067-1083

[13] Terpstra M. and Van Vean J.G Heat Pipes Construction and Application, London, New York, Elsevier Applied Science, 1987.

[14] Liu G., The application of heat pipe heat exchanger in exhaust gas heat recovery system and its thermodynamic analysis // proc. of 8th Int. Heat Pipe Conference, Beijing, China, 1992, pp. 582-585.

[15] Sun J.Y and Shyu R.J, Waste heat recovery using heat pipe heat exchanger for industrial practices // Proc. of 5th Int. Heat Pipe Symposium, Melburn, Australia, 1996.

[16] Dube V., Sauciuc I. and Akbarzadeh A. Design construction and testing of a thermosiyhon heat exchanger for medium temperature heat recovery // Proc. of 5th Int. Heat Pipe Symposium, Melburn, Australia, 1996.

[17] Xiau Ping, Wu, Johnson P. and Akbarzadeh A. A study of heat pipe heat exchanger ffectiveness in an air conditioning application // Proc. of 5th Int. heat Pipe Symposium, Melburn.

[18] Vasiliev L.L, Heat pipes for electronic equipment cooling system // Proc. of 7th Int. Heat Pipe Conference, Minsk, USSR, 1990.

[19] Basiulis A., Heat pipes for cooling of high density printed wiring board // Proc. of 6th Int. Heat Pipe Conference, Grenoble, France, 1987, pp. 685-691.

[20] Faghri, A. Heat pipes for hands // Mech. Eng., Vol. 111, No. 6, 1989b, pp. 72-75.

[21] Faghri, A. Temperature regulation system for the human body using heat pipes, US Patent 5,269,369, Issued 14th Dec. 1993.

[22] Brown R. Performance evaluation of the Grumman prototype space erectable radiator system Proc. of 25th Conference of AIAA, paper No.90-1766, 1990

[23] Brown R. Design of the SHARE II monogroove heat pipe // Proc. of 26th Thermophysics Conference of AIAA, paper No. 91-1359, 1991.

[24] Cotter, T.P.Theory of Heat Pipes, LA -3246-Ms,26 March 1965

[25] Leonard L. Vasiliev, Review Heat Pipes in Modern Heat Exchangers Applied Thermal Engineering 25(2005) 1-19 